\title{
EDITORIAL
}

\section{An appeal for theory that is beyond the self-referential in urban design research and thinking}

\author{
URBAN DESIGN International (2007) 12, 175-176. doi:10.1057/palgrave.udi.9000201
}

This is a special edition of Urban Design International. In contrast to previous editions, the journal is publishing one longer paper by Sandy Cuthbert entitled 'Urban Design: Requiem for an Era: Review and critique of the last 50 years'. The title itself suggests that it is an ambitious piece.

Cuthbert has recently had two books published. The first Designing Cities: Critical Readings in Urban Design (2003) presents a series of extracts which sum up, in Cuthbert's mind, the important readings in urban design. This book might sit along side readers such as those by Carmona and Tiesdell (2007) or the rather edited reader by Larice and Macdonald (2007). I say rather edited because sometimes I felt that core messages from original texts were not always as evident in the extracts presented in the latter book.

Cuthbert's reader was produced, however, also as a partner to his more significant second work The Form of Cities: Political Economy and Urban Design (2006), a book that fleshes out the author's argument for a more '... theoretical, philosophical and contextual foundation for the discipline and the meta-programmes that both form and legitimise practice' (p. 3).

As part of these works he also produced a third publication which until now was not published; an article which essentially reviewed and critiques what we might regard as the critical readings in this discipline, while in the process exposing the theoretical vacuum at the heart of much of this and other published work within the field. It takes a few words to present the review and construct the argument; enough words, I thought, for a special edition which would bring this incisive, critical and challenging article to a wider audience.

This article focuses on theory, but it is preoccupied with theory of urban design, rather than theory for urban design. Critically, however, it is felt that to understand any reasoning for thinking and practice that the 'of' has to be better addressed and resolved. Reading this article will not give you clues about how to become a better designer, whatever that might mean. It will, however, help us epistemologically, by allowing us to locate our work and the knowledge that we create in relation to fields of knowledge which have more rigorous academic traditions.

Cuthbert is polite about previous writings within our field, but he also essentially demolishes the work by arguing that, in what we might regard as key works, '...there is no cement binding the pieces together...', that they are self-referential 'perspectives' without scientific foundation, and that new works just add new perspectives. As a result the lists and tick boxes of design control or the flashy graphics of master planning or coding rest on weak foundations which hardly justify the professional and institutional effort made to create, maintain and implement them. We don't need another definition of urban design that merely, as Cuthbert argues, describes the surface. What we need is a body of knowledge that helps us understand '...the production and reproduction of urban form...' and our possible position, whoever we might be, within that process.

I suppose that this should be regarded as a moment of creative destruction. Cuthbert argues that urban design has more reason to exist as an academic discipline than architecture or urban planning, but that in its short life as an academic field it hasn't quite found its feet, possibly because it has been subsumed by the professional jostling and intellectual baggage of these and other related fields. There is a clear sense that Cuthbert wants us to break free and seek new allegiances within the social sciences. This is something that will certainly be easier for some of us than others, but whatever your starting 
point I hope that you find something in this paper that offers a window or mirror on your own academic work.

Mike Biddulph

City and Regional Planning, Cardiff University, Glamorgan Building, King Edward VII Avenue, Cardiff CF10 3WA, UK. E-mail: BiddulphMJ@cardiff.ac.uk

\section{References}

Carmona, M. and Tiesdell, S. (eds) (2007) Urban Design Reader. Oxford: Architectural Press.

Cuthbert, A.R. (2003) Designing Cities: Critical readings in urban design. Oxford: Blackwell.

Cuthbert, A.R. (2006) The Form of Cities: Political Economy and Urban Design. Oxford: Blackwell.

Larice, M. and Macdonald, E. (2007) The Urban Design Reader. London: Routledge. 